\title{
Combination of Vaccine Strain Measles Virus and Nimotuzumab in the Treatment of Laryngeal Cancer
}

\author{
NGUYEN LINH TOAN ${ }^{1 *}$, NGO THU HANG ${ }^{1,2^{*}}$, NGUYEN KIM LUU ${ }^{3}$, CAN VAN MAO $^{1}$, NGUYEN VAN BA ${ }^{3}$, \\ NGUYEN THI XUAN ${ }^{4}$, TRUONG DINH CAM ${ }^{5}$, NAOKI YAMAMOTO ${ }^{6}$, HOANG VAN TONG $^{1,7}$ and HO ANH SON ${ }^{1,7}$ \\ ${ }^{1}$ Department of Pathophysiology, Vietnam Military Medical University, Hanoi, Vietnam; \\ ${ }^{2}$ Ha Dong Medical College, Hanoi, Vietnam; \\ ${ }^{3} 103$ Military Hospital, Vietnam Military Medical University, Hanoi, Vietnam; \\ ${ }^{4}$ Institute of Genome Research, Vietnam Academy of Science and Technology, Hanoi, Vietnam; \\ ${ }^{5} 175$ Military Hospital, Ho Chi Minh, Vietnam; \\ ${ }^{6}$ Department of Microbiology, Yong Loo Lin School of Medicine, \\ National University of Singapore, Singapore, Singapore; \\ ${ }^{7}$ Institute of Biomedicine and Pharmacy, Vietnam Military Medical University, Hanoi, Vietnam
}

\begin{abstract}
Background/Aim: This study aims to investigate whether the combination of oncolytic viruses with chemoradiotherapy or other therapies is a promising strategy for cancer treatment. Materials and Methods: The anticancer effects of measles virus $(\mathrm{MeV})$ in combination with nimotuzumab in the treatment of laryngeal cancer were evaluated in vitro and in nude mice inoculated with Hep2 tumors. MTT assay and flow cytometry were used to examine cell death. Results: Laryngeal cancer cells treated with MeV+nimotuzumab combination had a significantly lower survival rate compared to those treated with $\mathrm{MeV}$ or nimotuzumab alone $(p<0.0001)$. In an animal model bearing human laryngeal tumor, the treated group had a higher survival rate (60\%) compared to a untreated group (20\%) $(p<0.05)$, and the survival rate of the group treated with MeV+nimotuzumab combination was higher compared to the groups received single treatment. Conclusion: The $M e V+$ nimotuzumab combination has greater anticancer activities in both laryngeal cancer cells and an animal model.
\end{abstract}

*These Authors share first co-authorship.

Correspondence to: A/Prof. Ho Anh Son, MD, Ph.D., Department of Pathophysiology, Vietnam Military Medical University, 160 Phung Hung Street, Ha Dong, Hanoi, Vietnam. Tel: +84 978437229 , e-mail: hoanhsonhp@gmail.com; A/Prof. Nguyen Linh Toan, MD, Ph.D., Department of Pathophysiology, Vietnam Military Medical University, 160 Phung Hung Street, Ha Dong, Hanoi, Vietnam. Tel: +84 979166868, e-mail: toannl@vmmu.edu.vn

Key Words: Oncolytic virus, Measles virus, nimotuzumab, cancer target, laryngeal cancer, monoclonal antibody.
Head and neck cancers rank fourth among the most popular malignant diseases and are one of the most common cancers in men worldwide (1). According to statistics in various countries, laryngeal cancer accounts for $2 \%$ of all cancers (2). The disease is diagnosed in more than 10,000 men and 3,000 women in the United States annually. Most of them are at the age of 65, and laryngeal cancer ranks second after nasopharyngeal cancers among head and neck cancers and ranks tenth among all cancers, with the high incidence among men aged 40-60 years (3).

Oncolytic virus (OLV) therapy is based on the property of oncolytic viruses to selectively infect and replicate in tumor cells, and subsequently either directly kill the infected cells or stimulate immune responses against tumor cells $(4,5)$. Among the viruses with oncolytic activities, Measles virus $(\mathrm{MeV})$ is the most systematically studied. It is a negativestrand RNA virus of the genus Morbillivirus that causes the infectious measles syndrome. In the urgent need for a new effective therapy for cancers, oncolytic virus-based therapy is a promising tool to complement current therapeutic strategies. The vaccine strain of $\mathrm{MeV}$ has been shown to have the capability to infect many cancer cell lines $(6,7)$. Although the exact mechanism by which $\mathrm{MeV}$ can enter and kill cancer cells is not fully understood, CD46, which is highly expressed on cell surface of most types of cancer cells, has been identified as one of the receptors of $\mathrm{MeV}(8)$. In addition, oncolytic virus has a high replication rate that can directly kill cancer cells and the vaccine strain of $\mathrm{MeV}$ has been demonstrated to be safe in humans (9). Therefore, $\mathrm{MeV}$ has a great potential to be used for cancer treatment.

The earliest in vitro and in vivo studies on attenuated $\mathrm{MeV}$ have demonstrated effective lysis of myeloma cell lines in vitro, as well as of cells of tumors implanted in a murine 
xenograft model (10). Data showed complete tumor regression following intratumoural $\mathrm{MeV}$ treatment or intravenous virus treatment (10). Intratumoral injection of $\mathrm{MeV}$ resulted in regression of large established human lymphoma xenografts whereas all tumors in the control group treated with UVinactivated virus progressed (11). The antitumor effect still occurred in the presence of anti-MeV antibody and intravenous administration of $\mathrm{MeV}$ also resulted in decelerating of tumor progression (12). Analysis of tumor sections confirmed replication of $\mathrm{MeV}$ within the tumors.

Epidermal growth factor receptor (EGFR) has been observed to be overexpressed in tumor tissues of head and neck cancer patients. EGFR plays an important role in cell growth, metastasis and proliferation of tumor cells promoting the development of head and neck cancers (13). nimotuzumab is a humanized monoclonal antibody that can bind specifically to EGFR and prevent the activation of the receptor (14). The combination of nimotuzumab with concurrent chemoradiotherapy is one of the strategies to treat several types of cancer such as esophageal cancer (15), advanced lung squamous cell carcinoma (LSCC) (16), and advanced nasopharyngeal carcinoma (17). Particularly, nimotuzumab combined with chemotherapy has been shown to have an increased effect and was suggested to be a first-line therapy for patients with LSCC (16). In addition, combination of nimotuzumab with concurrent chemoradiotherapy has been shown to have beneficial effect on advanced nasopharyngeal carcinoma (17).

Our earlier study has shown that the combination of vaccine-derived $\mathrm{MeV}$ and mumps virus $(\mathrm{MuV})$ efficiently targeted and killed a wide range of hematopoietic cancer cell lines, exhibited greater tumor suppression and resulted in prolonged survival in vivo (7). A convincing evidence for the anti tumor effect of $\mathrm{MeV}+\mathrm{MuV}$ combination on human solid cancers has also been demonstrated in another previous study (6). In this study, we aimed to investigate the anticancer and cytopathic effects of the combination of $\mathrm{MeV}$ and nimotuzumab on laryngeal cancer in vitro and in vivo.

\section{Materials and Methods}

Cell lines. Vero cell line (kidney, African green monkey) and human laryngeal squamous cell carcinoma Hep 2 cell lines (ATCC CCL23, laryngeal SCC) were purchased from the American Type Cell Culture (ATCC, Manassas, VA, USA). Vero cells were cultured in M199 medium (Biowest, Maine-et-Loire, France) supplemented with $10 \%$ Foetal Bovine Serum (FBS), $100 \mathrm{U} / \mathrm{ml}$ penicillin and 100 $\mu \mathrm{g} / \mathrm{ml}$ streptomycin (ATCC). Hep2 cells were cultured in Eagle's Minimum Essential Medium (EMEM) (ATCC-formulated F-12K) (Catalog No.30-2004) medium supplemented with $10 \%$ FBS, $100 \mathrm{U} / \mathrm{ml}$ penicillin and $100 \mu \mathrm{g} / \mathrm{ml}$ streptomycin in a $75 \mathrm{~cm}^{2}$ culture flash. The cells were maintained at $37^{\circ} \mathrm{C}$ in a humidified incubator with $5 \% \mathrm{CO}_{2}$. The cells were used at $80 \%$ confluence. The cells were harvested by using Trypsin EDTA, and centrifuged to remove the culture medium. The density of cancer cells was determined using Neubauer counters and optical microscopes. A standard density of $10^{7}$ cells $/ \mathrm{ml}$ was used in the experiments.

Propagation of measles viruses. $\mathrm{MeV}$ was plaque purified from Priorix (GlaxoSmithKline, UK) containing the attenuated measles virus (Schwarz MeV strain), mumps virus (RIT 4385 strain) and rubella virus (Wistar RA 27/3 RV strain) and was maintained in Vero cells. The procedure to prepare $\mathrm{MeV}$ for further experiments has been described in detail in our previous study (6). We also confirmed the presence of only $\mathrm{MeV}$ in each viral clone by using RT-PCR with specific primer pairs (6).

Death cell evaluation by MTT assay. The MTT assay was used to evaluate cell viability. This method is based on the principle that in living cells mitochondrial succinate dehydrogenase metabolizes 3-(4,5- Dimethylthiazol-2-yl)-2,5- diphenyltetrazolium bromide (MTT) (yellow) into formazan which is violet. When the cells are dead, the mitochondria are no longer able to convert MTT into a colorant formazan, which can be quantified by measuring optical density. The optical density measured by the MTT assay is proportional to the number of living cells (18). Cancer cells were harvested from cultured plates, divided equally in culture medium, adjusted at a density of $10^{4} \mathrm{cells} / \mathrm{ml}$, and transferred to 96-well plates. Each well contained $200 \mu \mathrm{l}$ of culture medium and 2,000 cells. After $24 \mathrm{~h}$ of incubation, when the cells adhered to the bottom of the wells, the old culture medium was removed and replaced with $200 \mu \mathrm{l}$ of new culture medium in the MeV 1MOI control wells, 200 $\mu \mathrm{l}$ new culture medium supplemented with $\mathrm{MeV}$ in the $\mathrm{MeV}$ group, $200 \mu \mathrm{l}$ new culture medium supplemented with nimotuzumab at a dose of $100 \mu \mathrm{g} / \mathrm{ml}$ in the nimotuzumab group. The MTT assay was performed following $72 \mathrm{~h}$ and $96 \mathrm{~h}$ incubation. The medium in the culture wells was completely removed and replaced with $90 \mu \mathrm{l}$ of fresh culture medium containing $10 \mu \mathrm{l}$ of MTT solution. The cells were incubated for $4 \mathrm{~h}$ to allow mitochondria to convert the yellow MTT into purple formazan crystals. Then, the culture medium was removed again and $100 \mu \mathrm{l}$ of MTT crystalline solution was added. Optical density (OD) was measured at $570 \mathrm{~nm}$ and the background OD was measured at $690 \mathrm{~nm}$.

Phosphatidylserine translocation and 7AAD incorporation. To discriminate necrotic/late apoptotic from early apoptotic cells by flow cytometry using the Annexin V/7AAD kit (Biolegend, CA, USA) according to the manufacturer's instructions. The presence of phosphatidylserine (PS) on the outer surface of the apoptotic cells was assessed from FITC-conjugated annexin V binding to PS at the cell surface and necrosis/late apoptosis was assessed from the amount of 7AAD-positive cells. In brief, approximately $10^{6}$ cells (human laryngeal squamous cell carcinoma Hep2 cell line) were seeded in each $60 \mathrm{~mm}$ cell culture dish with EMEM, 10\% FBS, 100 $\mathrm{U} / \mathrm{ml}$ penicillin and $100 \mu \mathrm{g} / \mathrm{ml}$ streptomycin for $24 \mathrm{~h}$ before treatment. The cells were then treated with control medium, $\mathrm{MeV}$, nimotuzumab or $\mathrm{MeV}+$ nimotuzumab combination. Apoptosis was assayed at 48,72 and $96 \mathrm{~h}$ after treatment.

Quantification of gene expression by RT-PCR. Human laryngeal squamous cell carcinoma Hep 2 cell lines cultured in EMEM medium were harvested in trypsin EDTA bottles by centrifuging to remove the culture medium. Cell density was determined using Neubauer counters and a microscope. $10^{6}$ laryngeal tumor cells were used for total RNA isolation by using total RNA isolation kit 


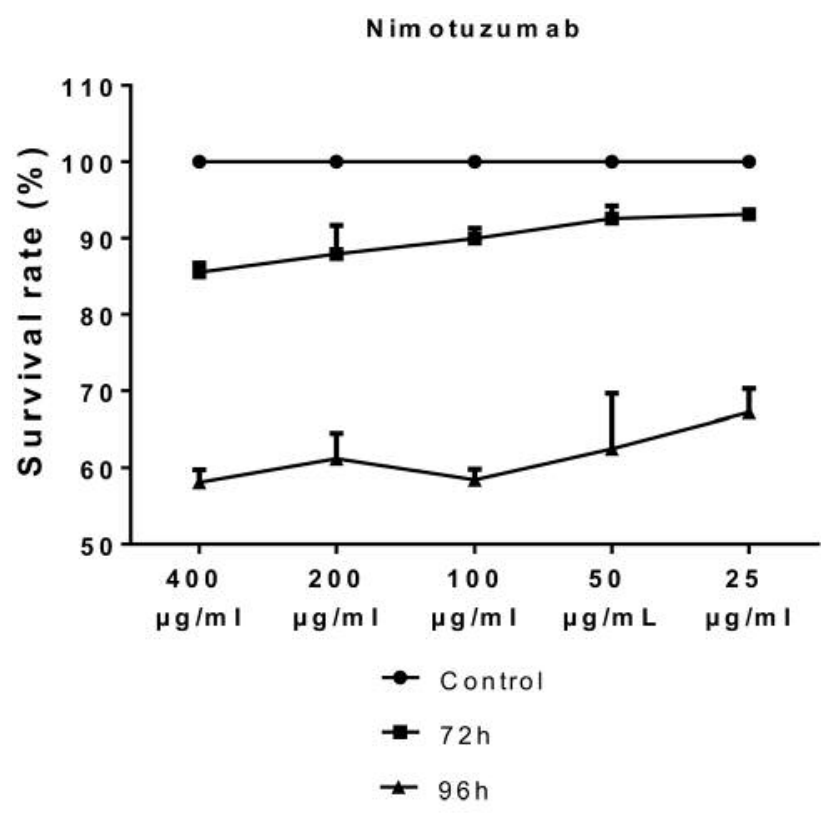

Figure 1. Anticancer effect of nimotuzumab at different concentrations. A total of $10^{6}$ laryngeal cancer cells (Hep2) were cultured and treated with different concentrations of nimotuzumab $(400,200,100,50$ and 25 $\mu \mathrm{g} / \mathrm{ml})$. MTT assay was used to evaluate the survival rate of Hep2 cells at 72 and $96 \mathrm{~h}$.

(Qiagen, Hilden, Germany) following the instructions of the manufacturer. RNA was reversely transcribed into cDNA by using RevertAid First Strand cDNA Synthesis Kit (Thermo Fisher Scientific, MA, USA). Quantification of STAT3 and ISG15 genes was performed by qRT-PCR, and GAPDH (glyceraldehyde-3phosphate dehydrogenase) was used as a reference gene. The reaction contained: $10 \mu \mathrm{l}$ of $2 \times$ SYBR Green PCR master mix (Enzynomics, Daejeon, South Korea), $0.4 \mu \mathrm{M}$ of forward and reverse primers for the reference and target genes, $50 \mathrm{ng}$ of cDNA and $6 \mu \mathrm{l}$ and RNase-free water (Qiagen, Hilden, Germany) in a final volume of $20 \mu \mathrm{l}$. All reactions were performed in duplicate and were repeated twice. Primer sequences used were: STAT3 (sense): 5'GGA GGA GTT GCA GCA AAA AG-3'; STAT3 (antisense): 5'TGT GTT TGT GCC CAG AAT GT-3' (19); ISG15 (sense): 5'GAG AGG CAG CGA ACT CAT CT-3'; ISG15 antisense: 5'-CTT CAG CTC TGA CAC CGA CA-3'. GAPDH (sense): 5'-TTG GTA TCG TGG AAG GAC TCA-3'; GAPDH (antisense): 5'-TGT CAT CAT ATT TGG CAG GTT-3'. (20) Thermal cycling conditions were: $2 \mathrm{~min}$ at $95^{\circ} \mathrm{C}$ followed by 45 cycles of denaturation for $5 \mathrm{sec}$ at $95^{\circ} \mathrm{C}$, annealing for $20 \mathrm{sec}$ at $52^{\circ} \mathrm{C}$ for STAT3, $58^{\circ} \mathrm{C}$ for $I S G 15$ and $50^{\circ} \mathrm{C}$ for $G A P D H$ and extension for $20 \mathrm{sec}$ at $72^{\circ} \mathrm{C}$. Reaction specificity was confirmed by melting curve analyses starting from $50^{\circ} \mathrm{C}$ to $85^{\circ} \mathrm{C}$. The fold change of STAT3 and ISG15 was normalized using the $\triangle \mathrm{Ct}$ method against the expression of GAPDH.

Animal experiments. Six to eight-week old male BALB/c nude mice were purchased from BioLASCO (Taipei City, Taiwan) and were kept under pathogen-free conditions in accordance with Animal Center Guidelines. The procedures were approved by the Vietnam Military Medical University, Vietnam (072/13). To evaluate the effect of MeV,

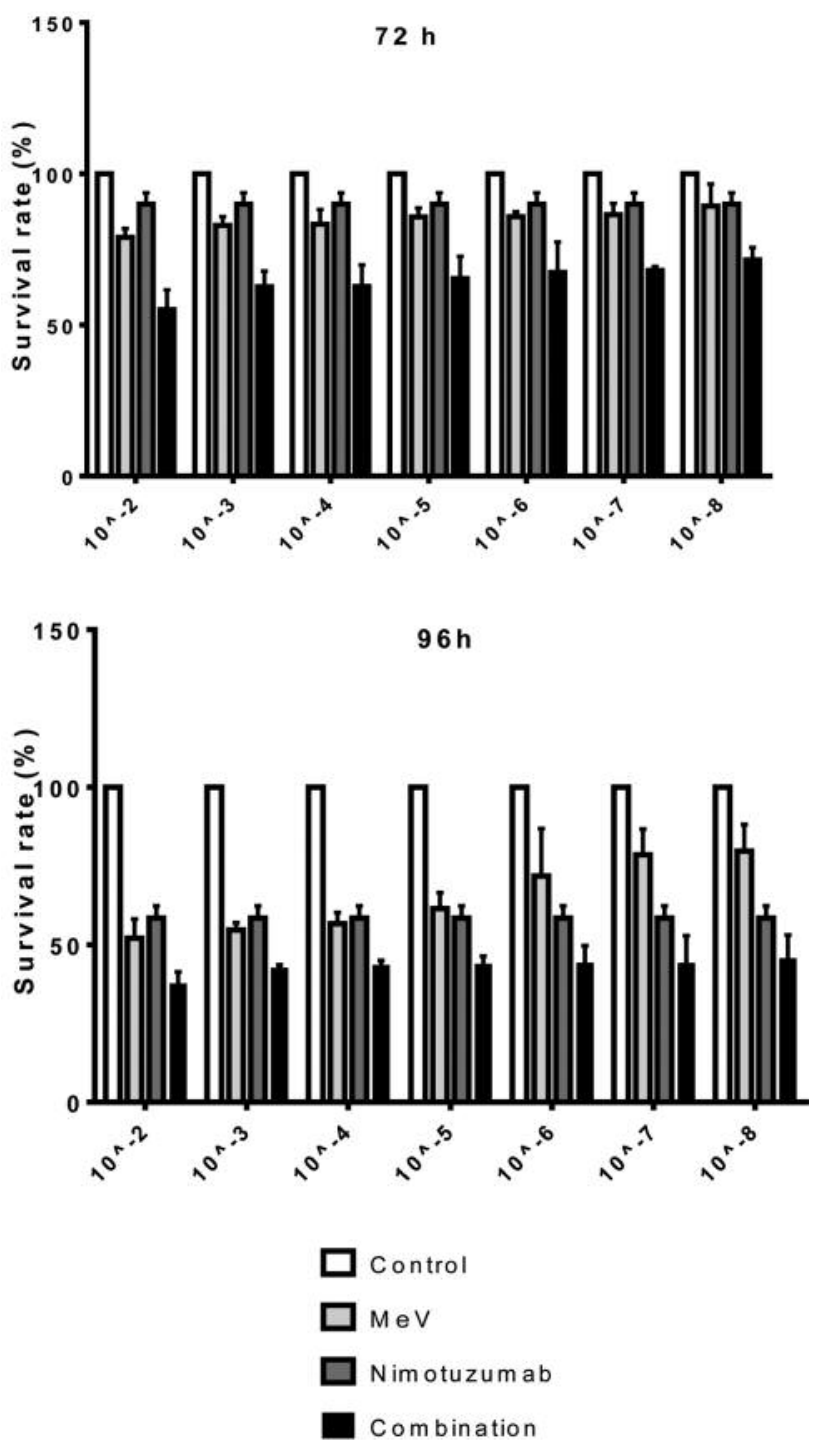

Figure 2. Anticancer effects of $\mathrm{MeV}$ and nimotuzumab in vitro. A total of $10^{6}$ laryngeal cancer cells (Hep2) were cultured and treated with $\mathrm{MeV}$, nimotuzumab alone, or with MeV+nimotuzumab combination. Non-treated cells were used as control. MTT assay was employed to evaluate the survival rate of Hep2 cells at 72 and $96 h$.

nimotuzumab or $\mathrm{MeV}+$ nimotuzumab combination on tumor growth and survival time of nude mice bearing Hep2 tumors, the mice were inoculated with $10^{6} \mathrm{Hep} 2$ cells in $100 \mu \mathrm{FBS}$ on the right rear flanks of male nude mice. One week after inoculation, the formation of tumor in mice was checked twice per week, when the tumor reached the size of $7-10 \mathrm{~cm}$ in diameter, the mice were divided into 4 groups, and each group consisted of 10 mice. The mice were treated with PBS as control, $\mathrm{MeV}$, nimotuzumab or $\mathrm{MeV}+$ nimotuzumab combination. They received a single dose $\left(10^{6} \mathrm{CFU} /\right.$ mouse/time $)$ or multiple doses ( $10^{7} \mathrm{CFU} /$ mouse/time, twice a week for 3 weeks) by intratumor injection. Tumor volume and survival time were observed and recorded. Tumor volume was calculated from caliper measurements 


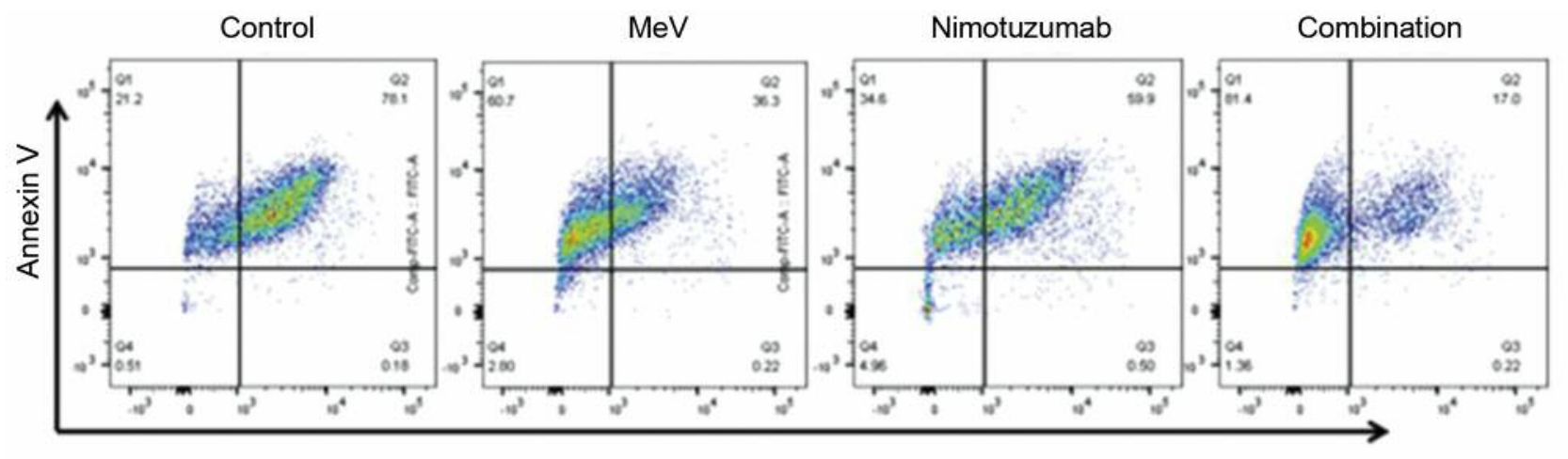

7-Amino actinomycin D

$48 \mathrm{~h}$

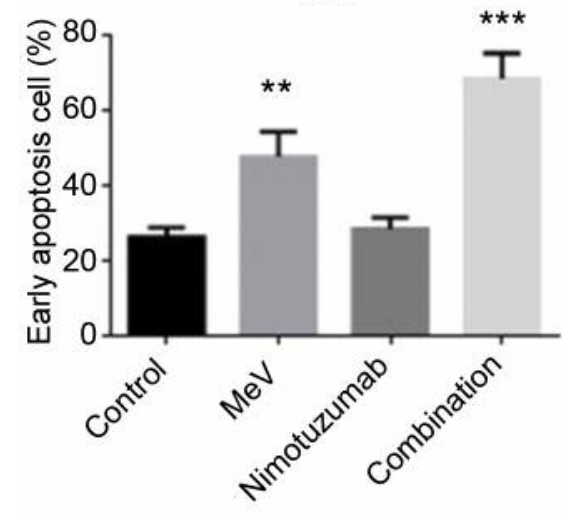

$72 \mathrm{~h}$

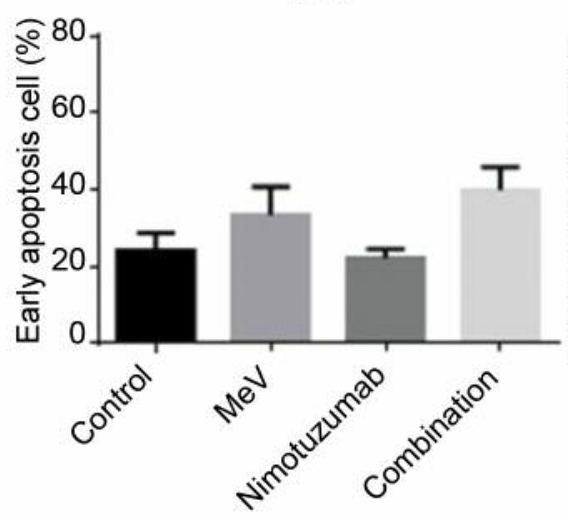

$96 \mathrm{~h}$

Figure 3. Apoptosis induction by $\mathrm{MeV}$ and nimotuzumab treatment of laryngeal cancer cells. A total of $10^{6}$ laryngeal cancer cells (Hep2) were cultured and treated with MeV, nimotuzumab alone, or MeV+nimotuzumab combination. Non-treated cells were used as control. Apoptotic cells were detected after 48, 72 and 96 h after treatment. Original dot plots of early-stage apoptotic cells (Annexin $V^{+} / 7 A A D^{-}$laryngeal cancer cells, in upper left quadrant) detected $48 \mathrm{~h}$ after treatment by flow cytometry (upper panels). Arithmetic means $\pm S D$ of the percentage of Annexin $V^{+} / 7 A A D^{-}$ cells in untreated cells (control) or cells treated with MeV, nimotuzumab alone, or MeV+nimotuzumab combination for 48 h (1st lower panel), $72 h$ (2nd lower panel) and 96 h (3rd lower panel); (**), $p<0.01$ and $(* * *), p<0.0001$ compared with other groups.

of length and width of masses (volume $\left(\mathrm{mm}^{3}\right)=$ length $\times 1 / 2 \times$ width 2 ). Relative tumor volume was calculated as the volume at a given time divided by the volume on the indicated time points after initiation of treatment.

Analysis of tumor cell structure by Transmission electron microscopy. Biopsy samples of Hep2 tumors were washed twice with cacodylate buffer solution $\mathrm{pH} 7.3$ then fixed with glutaraldehyde $2 \%$ in a cacodylate buffer ( $\mathrm{pH}$ 7.3) with a ratio of sample volume and solution volume of 1:10 for 2 to 3 days. The samples were divided into small pieces with size of $1 \times 1 \times 2 \mathrm{~mm}$, washed $2-3$ times in $1 \mathrm{~h}$ with cacodylate buffer, fixed with $1 \%$ osmic acid in cacodylate buffer $(\mathrm{pH}$ 7.3) for $1 \mathrm{~h}$, and washed again 2-3 times with cacodylate buffer $(\mathrm{pH}$ 7.3). The samples were then dehydrated by consecutively transferring them for 15 min to different alcohol solutions of $50 \%, 60 \%, 70 \%$, $80 \%, 90 \%$, and $100 \%$. After dehydration, the samples were transferred for $10 \mathrm{~min}$ to a solution of propylene+ethylene (1:1 ratio in volume), then passed to propylene solution for $10 \mathrm{~min}$. The samples were moved to a mixture of propylene+epon 812 with a volume ratio of $1: 1$ for $15 \mathrm{~min}$ followed by a propylene+epon 812 mixture of 1: 2 in volume for $30 \mathrm{~min}$. Finally, the samples were moved to epon 812 for $30 \mathrm{~min}$, blocked and maintained at $37^{\circ} \mathrm{C}$ for $24 \mathrm{~h}$ and polymerized at $60^{\circ} \mathrm{C}$ for $48 \mathrm{~h}$. Subsequently, the sample blocks were thinly cut, stained with toluidine blue and were cut by a microtome (Walldorf, Germany) at thickness of $50 \mathrm{~nm}$. The slides were put in a 200-hole copper net, stained with $2 \%$ uranyl acetate for 5 min, washed twice with distilled water and stained with 5\% lead citrate for $5 \mathrm{~min}$, and washed twice with distilled water. The sections were observed under the transmission electron microscopy (TEM) JEM 1400 (JEOL, Japan).

Statistical analysis. Data were analyzed with the GraphPad Prism 5.0 software (GraphPad Software, CA, USA) and SPSS v.20 (SPSS Statistics, IBM, Armonk, NY, USA). Student's $t$-test, Mann-Whitney $U$-test or Fisher's exact test was applied to compare groups. The Kaplan-Meier method and the log-rank test were used to compare the survival time of nude mice between groups. Statistical significance was defined as $p$-value $\leq 0.05$. 
IS G 15 expression

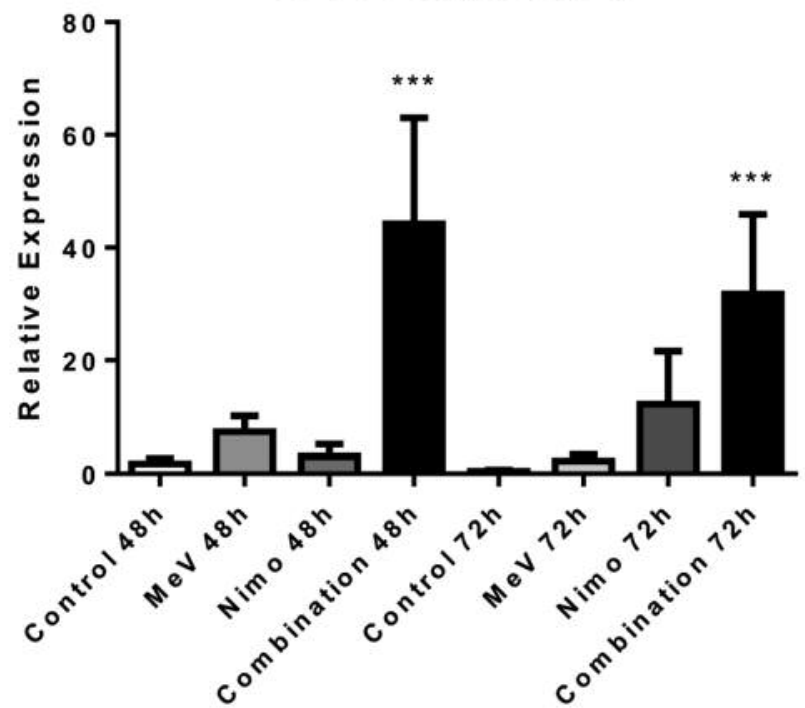

STAT3 expression

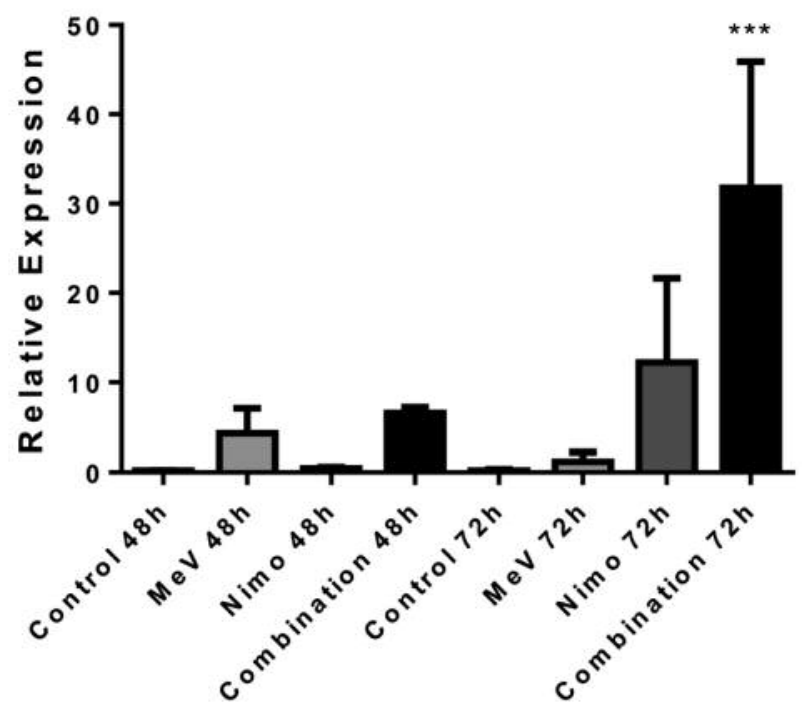

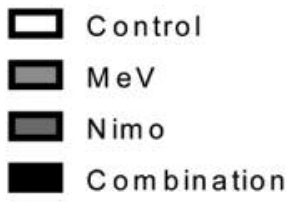

Figure 4. Expression of ISG15 and STAT3 genes in laryngeal cancer cells. Laryngeal cancer cells were treated for $48 \mathrm{~h}$ and $72 \mathrm{~h}$ with PBS, MeV, nimotuzumab and MeV+nimotuzumab combination. Relative expression of ISG15 and STAT3 was quantified by real-time PCR and calculated by the $\triangle C t$ method normalized with GAPDH as a reference gene. The levels of relative expression were compared between groups and p-value was calculated by the ANOVA test, $(* * *), p<0.0001$ compared to other groups.

\section{Results}

Anti tumor effects of MeV+nimotuzumab treatment against laryngeal cancer in vitro. The anticancer effects of different concentrations (400 $\mu \mathrm{g} / \mathrm{ml}, 200 \mu \mathrm{g} / \mathrm{ml}, 100 \mu \mathrm{g} / \mathrm{ml}, 50 \mu \mathrm{g} / \mathrm{ml}$ and $25 \mu \mathrm{g} / \mathrm{ml}$ ) of the monoclonal antibody nimotuzumab on the laryngeal cancer cell line (Hep2) were examined. The result showed that nimotuzumab treatment resulted in a concentration-depended increase in laryngeal cancer cell death (Figure 1). In addition, the $\mathrm{IC}_{50}$ of nimotuzumab were $2146 \mu \mathrm{g} / \mathrm{ml}$ and $876.9 \mu \mathrm{g} / \mathrm{ml}$ when determined at $72 \mathrm{~h}$ and $96 \mathrm{~h}$ post-infection, respectively.

Subsequently the effect of $\mathrm{MeV}$, nimotuzumab and $\mathrm{MeV}+$ nimotuzumab combination on the viability of Hep2 laryngeal cancer cells) was examined at $100 \mu \mathrm{g} / \mathrm{ml}$ nimotuzumab. Hep2 cells were infected and cell death was measured at 72 and $96 \mathrm{~h}$ post-infection. The results showed that $\mathrm{MeV}$ also had a strong killing effect on Hep2 cells compared to control. Remarkably, treatment with $\mathrm{MeV}$ and nimotuzumab (MeV+nimotuzumab) combination sh owed a significantly stronger anticancer activitiy compared to treatment with $\mathrm{MeV}$ or nimotuzumab alone as well as compared to control at both $72 \mathrm{~h}$ and $96 \mathrm{~h}$ post-infection (Figure 2).

MeV+nimotuzumab treatment induces apoptosis. Next, the mechanism by which $\mathrm{MeV}$ and nimotuzumab treatment results in cell death was examined. Laryngeal cancer cells were infected with $\mathrm{MeV}$, nimotuzumab or $\mathrm{MeV}+$ nimotuzumab combination, and apoptosis was assayed by flow cytometry using staining with Annexin-V. The results showed that the percentage of apoptotic cells (Annexin $\mathrm{V}^{+} / \mathrm{PI}^{-}$) was significantly higher in the group treated with $\mathrm{MeV}+$ nimotuzumab combination compared to the groups treated with $\mathrm{MeV}$ or nimotuzumab alone at 48, 72 and $96 \mathrm{~h}$ (Figure 3, upper panel). However, higher rate of early apoptotic cells was observed in the group treated with $\mathrm{MeV}+$ nimotuzumab combination at only $48 \mathrm{~h}$ post-infection (Figure 3, middle panel), and higher rate of late apoptotic cells was observed in the group treated with $\mathrm{MeV}+$ nimotuzumab combination at only $96 \mathrm{~h}$ post-infection (Figure 3, lower panel). These results indicated that the enhancement of the cytotoxic effect by $\mathrm{MeV}+$ nimotuzumab combination is due to increased induction of apoptosis. 

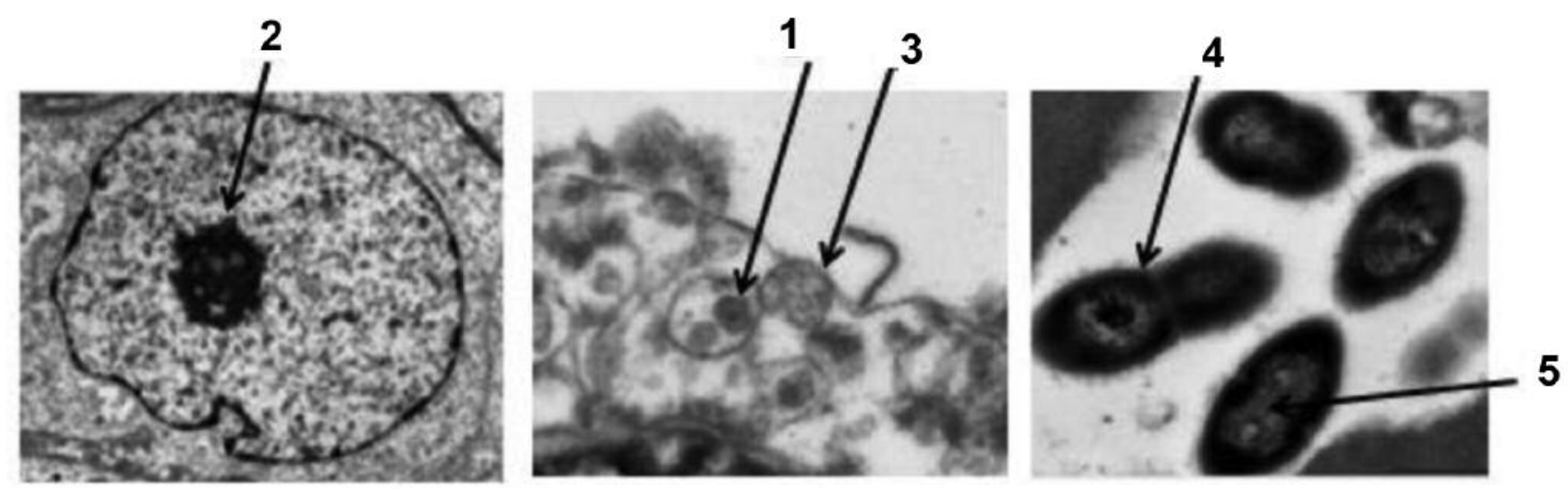

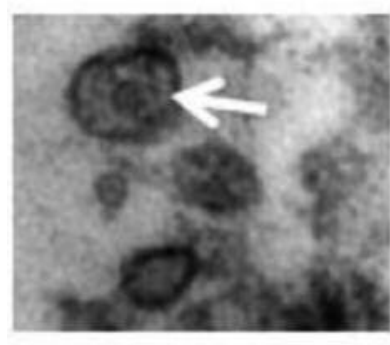

A

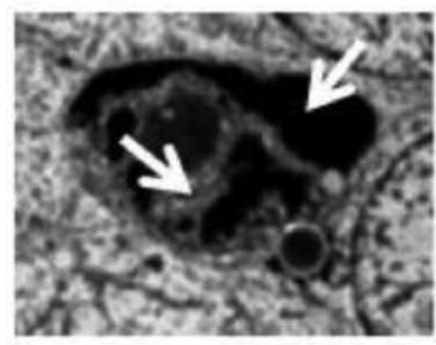

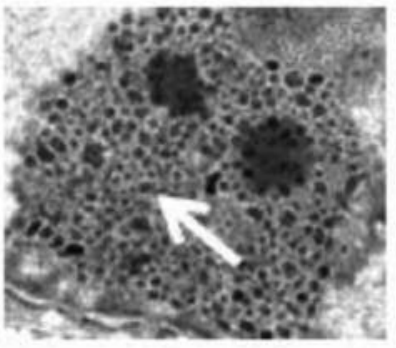

B

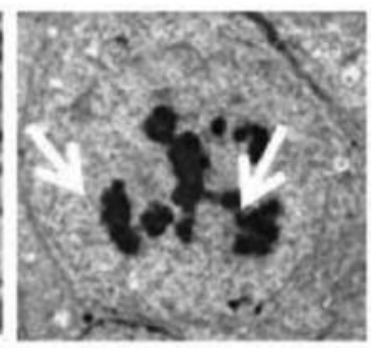

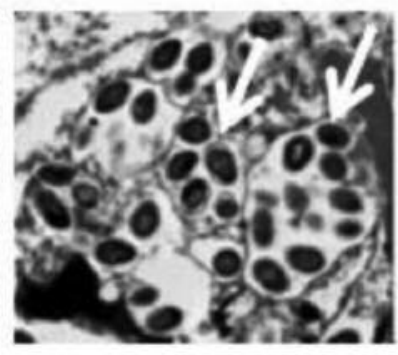

C

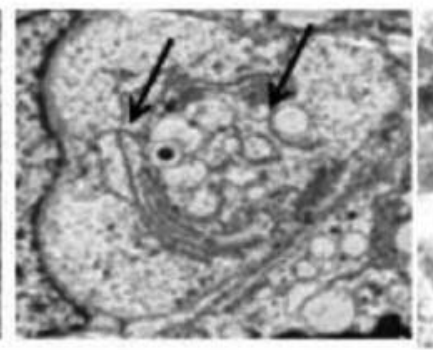

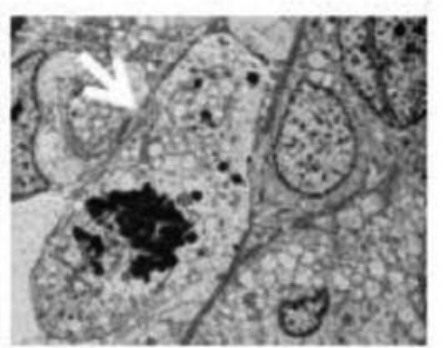

D

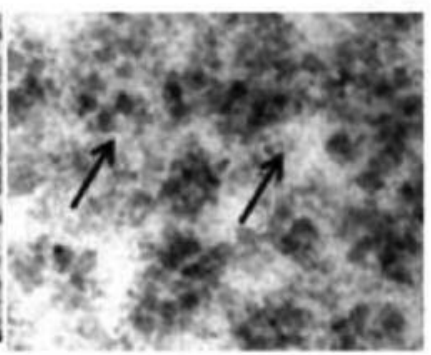

Figure 5. Analysis of the structure of laryngeal tumor cells before and after treatment by electron microscope. Upper panel: Normal structure of laryngeal tumor cells before treatment with $\mathrm{MeV}$, nimotuzumab or MeV+nimotuzumab combination. (1), normal structure of laryngeal tumor cells; (2), nucleus; (3), mucous membrane; (4, 5), dividing cells. Middle panel: Structure of laryngeal tumor cells after treatment with MeV, nimotuzumab or MeV+nimotuzumab combination. (A), Untreated cells; (B), laryngeal tumor Hep2 cells infected with MeV; (C, D), syncytia of cells that result from cell fusions. Lower panel: (E), Hep2 laryngeal tumor cells with chromosome condensation; $(F)$, Hep2 laryngeal tumor cells with chromosome fragmentation; $(G)$, Hep2 laryngeal tumor cells with many vacuoles; $(H)$, necrotizing cells.

STAT3 and ISG15 are proteins that play an important role in cancer development and apoptosis $(21,22)$. Therefore, the expression of STAT3 and ISG15 genes was examined in the laryngeal cancer cell line $48 \mathrm{~h}$ and $72 \mathrm{~h}$ post-infection. The results showed that the relative expression of STAT3 and ISG15 genes was highest in the groups treated with $\mathrm{MeV}+$ nimotuzumab combination compared to the groups treated with $\mathrm{MeV}$ or nimotuzumab alone at both $48 \mathrm{~h}$ and 72 h post-infection (Figure 4). This result suggested that MeV and nimotuzumab might induce apoptosis through STAT3 and ISG15 signaling pathways.
Then assessed the morphological changes in laryngeal cancer cells undergoing apoptosis. Laryngeal cancer cells (Hep2) were transplanted into nude mice to form tumors. After treatment with $\mathrm{MeV}$ and nimotuzumab, the tumors were biopsied to observe the structure of tumor cells by electron microscopy. Untreated Hep2 cells had round nuclei, dark color, clear boundaries, intact organs, and capillaries were observed at the outer surface of the cells (Figure 5, upper panel). Whereas, in the treated tumors, $\mathrm{MeV}$ infected cells were observed and the Hep2 tumor cells formed large, multi-nucleated, dark-colored syncytia resulting from cell 


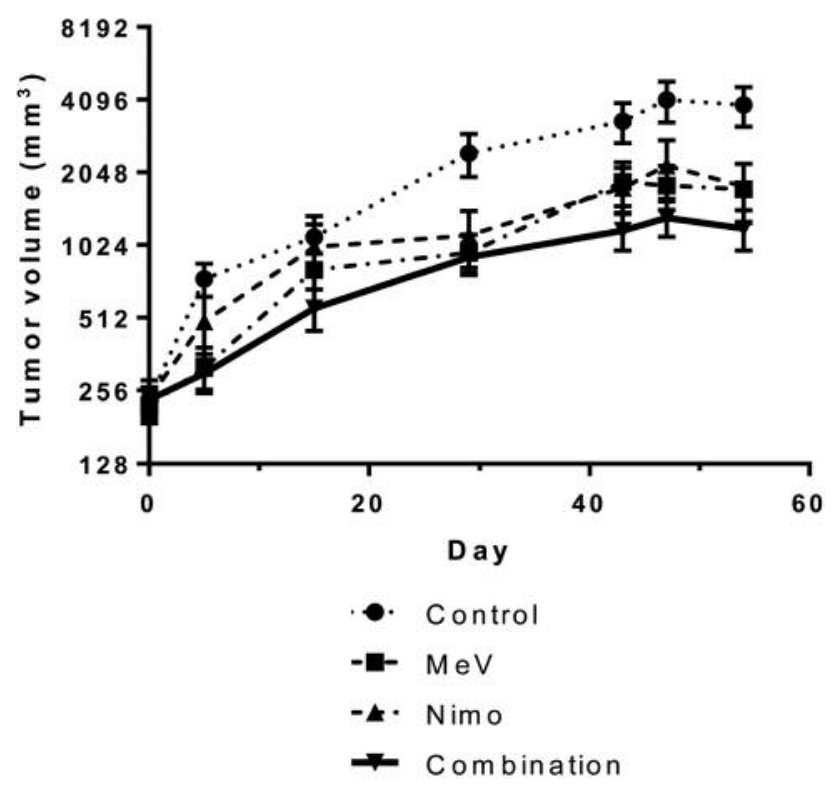

Figure 6. Anti tumor effect of MeV, nimotuzumab or MeV+nimotuzumab combination in a laryngeal cancer xenograft tumor model. Mice bearing laryngeal tumors were infected intratumorally with multiple doses of $P B S, M e V$, nimotuzumab or MeV+nimotuzumab combination (twice per week for 3 weeks). Tumor volume and survival time were recorded after treatment and during a 60 days of follow-up.

fusions (Figure 5, middle panel). We also observed Hep2 tumor cells in the process of apoptosis; rounded cells, microvascular lesions, nuclear fragmentation, chromosome condensation, lipid droplets, and appearance of multiple cytoplasmic vacuoles, as well as necrotizing cells (Figure 5, lower panel). The results indicated that treatment with $\mathrm{MeV}$ and nimotuzumab targets tumor cells and induces the apoptotic process.

Anti tumor effects of MeV+nimotuzumab treatment in mouse model with laryngeal cancer. The tumor suppressive effect of $\mathrm{MeV}$, nimotuzumab or $\mathrm{MeV}+$ nimotuzumab combination was examined in human laryngeal cancer xenograft tumor model. Mice bearing laryngeal tumor were injected intratumorally with multiple doses of $\mathrm{MeV}$, nimotuzumab or $\mathrm{MeV}+$ nimotuzumab combination (twice per week for 3 weeks). Tumor size and survival time were examined at different time points (on days $5,15,29,40,43,47,54$ and day 60 ) after treatment. The results showed that the tumor volume was increasing after transplantation of laryngeal cancer cells into the mouse and after treated with $\mathrm{MeV}$, nimotuzumab and $\mathrm{MeV}+$ nimotuzumab combination. However, the tumor volume in the treatment groups was increasing at a slower rate compared to the control group at all time points examined (Figure 6). On day 43, 47 and 54 , the tumor volume in the treatment groups was significantly smaller compared to control $(p<0.0001)$, and tumor volume in the group treated with $\mathrm{MeV}+$ nimotuzumab combination was also significantly smaller compared to groups treated with $\mathrm{MeV}$ or nimotuzumab alone (Figure 7).

During follow-up, eight mice in the control group died on day $12,15,33,36,40,43$, and day 57 ; four mice in the group treated with $\mathrm{MeV}$ died on day 22, 29, 47, and day 54; six mice in the group treated with nimotuzumab died on day 15 , $22,40,47$, and day 54; while only two mice in the group treated with $\mathrm{MeV}+$ nimotuzumab combination died on day 54 and day 57. After 60 days of follow-up, the survival rate in the treated group was $60 \%(18 / 30)$, which was significantly higher compared to the untreated group $(2 / 10,20 \%)$ $(p<0.05)$ (Figure 8). This result indicated that treatment with $\mathrm{MeV}$ and nimotuzumab increased the survival rate in the human laryngeal cancer xenograft tumor model.

\section{Discussion}

Cancer therapy based on oncolytic virus using vaccine strains is new strategy due to the great advantages such as safety and capability to target a wide range of cancer cell types. Previously, we have shown that the combination of vaccine strains $\mathrm{MeV}$ and $\mathrm{MuV}$ efficiently targeted and killed a number of hematopoietic cancer cells and cells of human solid malignancies in vitro and in vivo $(6,7)$. In this study, $\mathrm{MeV}$ in combination with nimotuzumab was found to have a greater anti cancer effect against laryngeal cancer cells compared to treatment with $\mathrm{MeV}$ or nimotuzumab alone. Treatment with $\mathrm{MeV}+$ nimotuzumab combination increased cytopathic activities and promoted apoptosis by stimulating cellular signaling pathways such as EGFR, ISG15 and STAT3 pathways. Treatment with MeV+nimotuzumab combination had anti cancer effect in a mouse model of head and neck cancer as was indicated by the reduction of tumor sizes and the increase in survival rate.

Several studies have shown that $\mathrm{MeV}$ exhibits a great antitumor effect in bone marrow (23) and neurological cancers (24). Galanis et al. have used measles viruses to treat 21 patients with ovarian cancer who had been previously treated with Taxol and Platinum (25). The results indicated that patients who were treated with measles viruses had twice longer survival time (12,5 months) compared to the untreated group (6 months) without side effects (25). In this study, we also observed a strong oncolytic activity of $\mathrm{MeV}$ in laryngeal cancer cells and cytotoxicity was mediated by virus replication and apoptosis induction. This observation is in line with several previous studies demonstrating that $\mathrm{MeV}$ can induce cancer cell apoptosis (26-28).

Oncolytic virus therapy is based on the property of oncolytic viruses to selectively enter tumor cells through the CD46 receptor, which is abundantly expressed on the surface of tumor cells, including laryngeal cancer (8). Once oncolytic 
Day 0

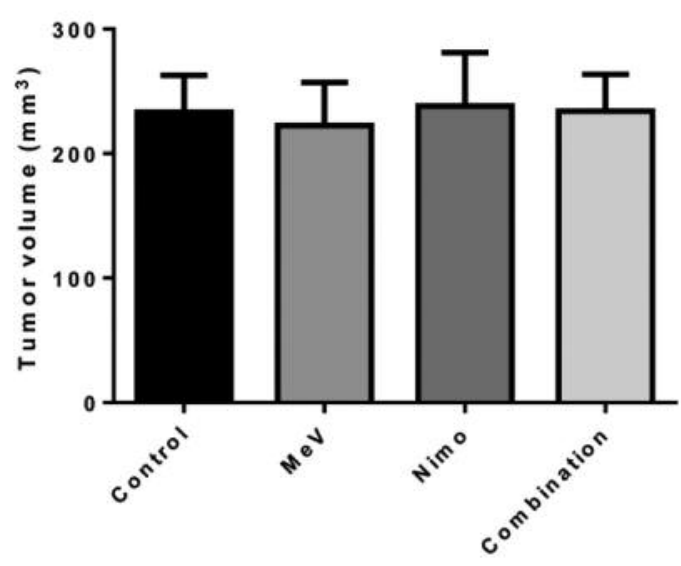

Day 15

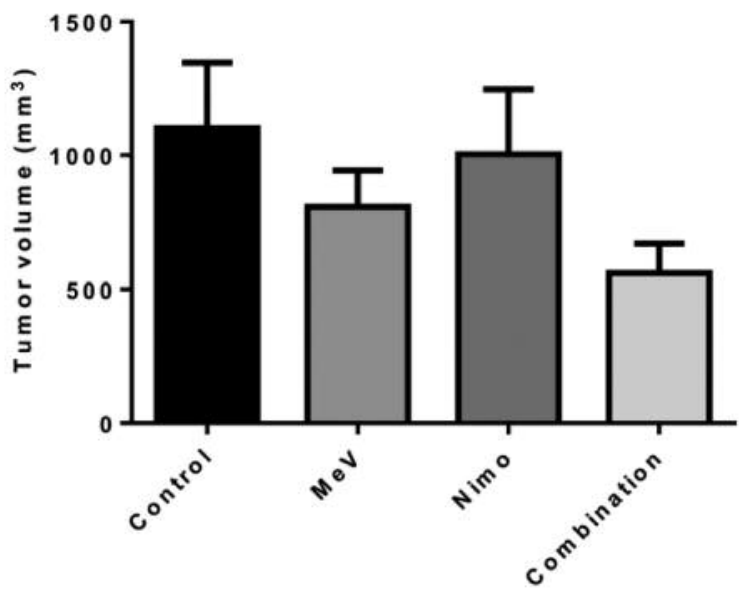

D ay 47

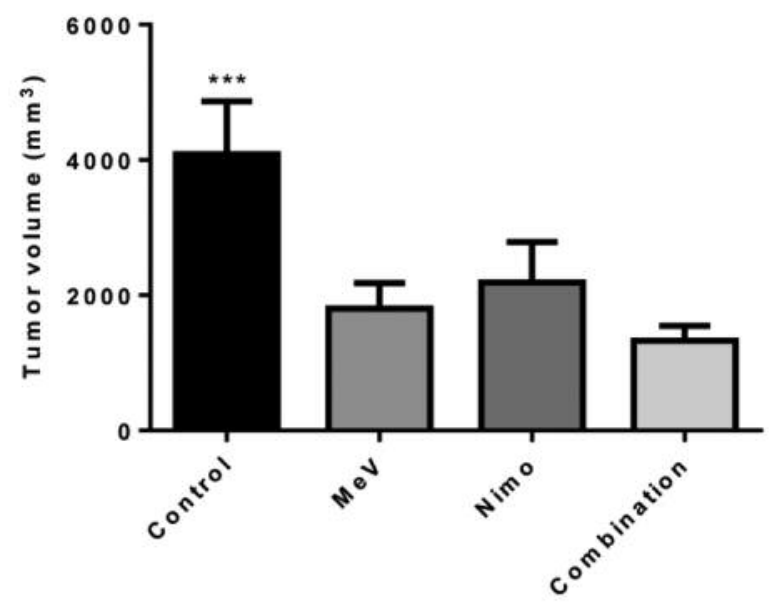

Day 5

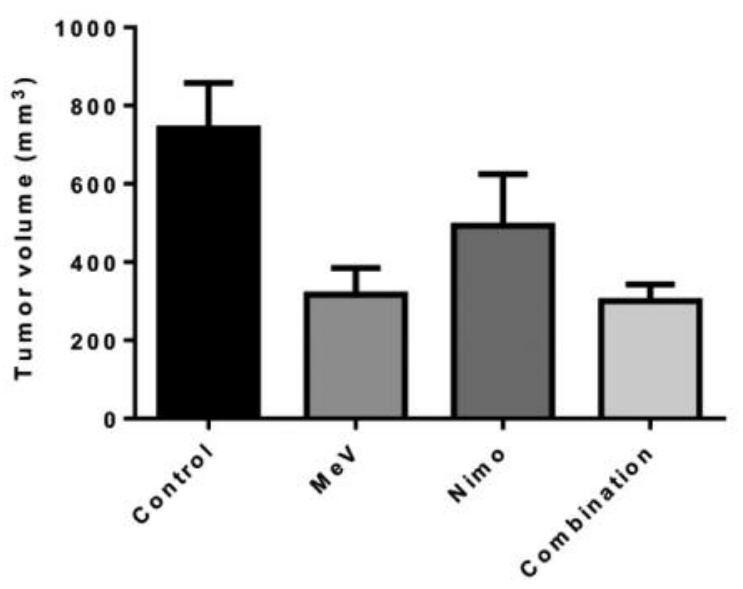

Day 43

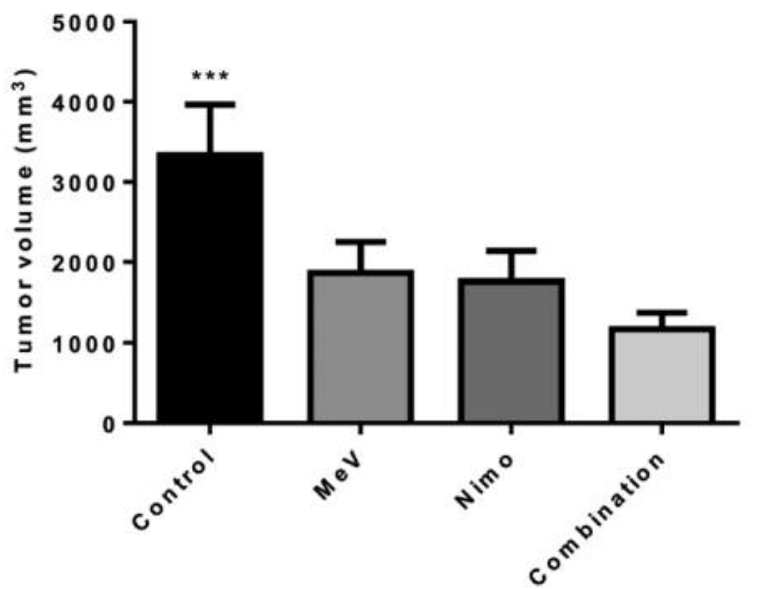

Day 54

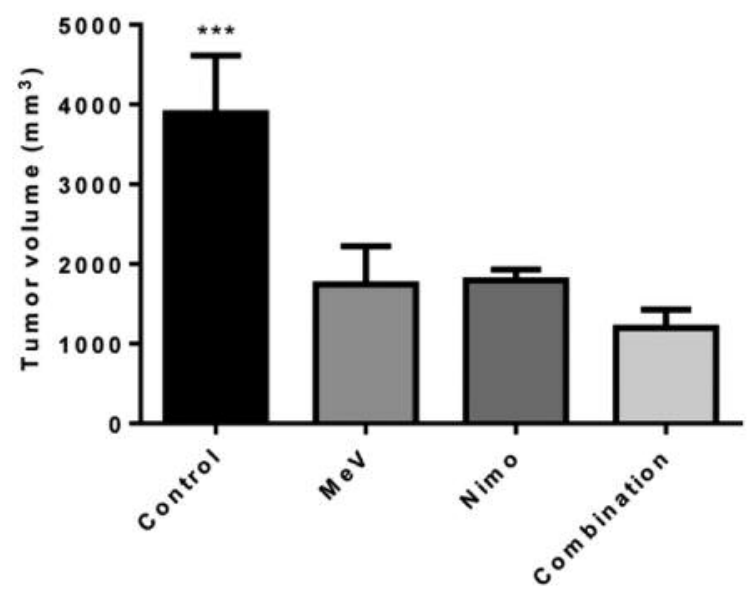

Figure 7. Comparison of anti tumor effect between single and combined treatment in a laryngeal cancer xenograft tumor model. Mice bearing laryngeal tumors were infected intratumorally with multiple doses of PBS, MeV, nimotuzumab or MeV+nimotuzumab combination (twice per week for 3 weeks). Tumor volume and survival time were recorded and compared between groups after treatment at day 0, day 5, day 15, day 43, day 47 and day 54. Data are mean $\pm S D$ of measurements obtained from 5 mice per group and $(* * *), p<0.0001$ compared to other groups. 


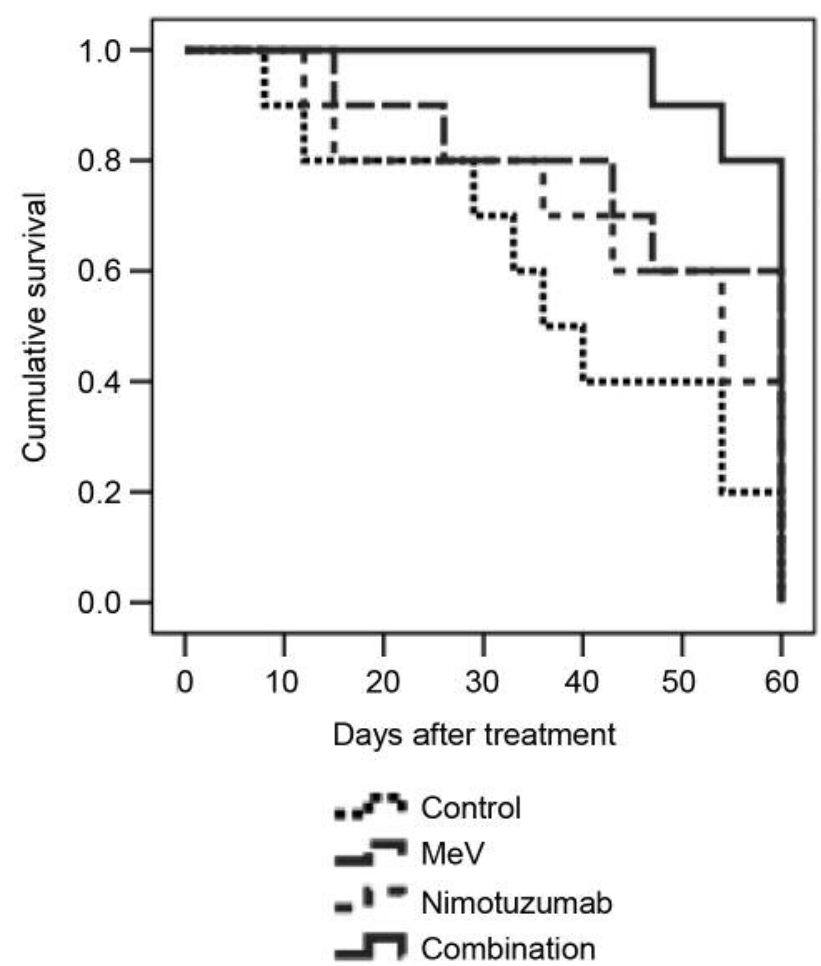

Figure 8. Survival time of nude mice bearing laryngeal tumor during 60 days follow-up. Mice bearing laryngeal tumor were intratumorally treated with $\mathrm{PBS}, \mathrm{MeV}$, nimotuzumab or MeV+nimotuzumab combination (twice per week for 3 weeks). Survival time was recorded after treatment during 60 days follow-up.

viruses infect tumor cells, its high replication rate results in the lysis of tumor cells. Subsequently, the newly produced oncolytic viruses continuingly infect other cancer cells (29). In the current study, $\mathrm{MeV}$ infected laryngeal tumor cells were observed in accordance with our previous studies detecting RNA of MeV and MuV in a number of cancer cell lines $(6,7)$. Oncolytic viruses may have anti cancer effects by stimulating an immune response against tumor cells, that is mediated by a number of unspecific innate immune cells such as NK, NKT cells and neutrophils $(4,5)$. Particularly, it has been shown that $\mathrm{MeV}$ induces expression of HSP72 and activates the immune system by stimulating NK cell activity and enhancing tumorantigen presentation to professional antigen presenting cells (30). A study has showed that vaccine strain $\mathrm{MeV}$ infects and replicates within neutrophils and also stimulates neutrophils to secrete several specific antitumor cytokines (IL-8, TNF- $\alpha$, MCP-1, and IFN- $\alpha$ ), suggesting a neutrophil-mediated mechanism for the attenuated $\mathrm{MeV}$ vaccine antitumor activities (31). Our previous studies have also demonstrated that treatment with $\mathrm{MeV}, \mathrm{MuV}$ and $\mathrm{MeV}+\mathrm{MuV}$ combination significantly enhanced spleen-infiltrating lymphocyte populations such as macrophages, NK and dendritic cells (6).
EGFR plays a crucial role in the pathogenesis of head and neck squamous cell carcinoma (HNSCC). Specifically, overexpression of EGFR and its ligand TGF $\alpha$ has frequently been observed in HNSCC, and the presence of high levels of EGFR and TGF $\alpha$ mRNA has also been observed in tumor tissues as $92 \%$ and $87 \%$, respectively (13). nimotuzumab is able to bind specifically to EGFR and prevent the activation of the receptor (14). nimotuzumab recognizes the extracellular domain of EGFR, competently binds to EGFR and prevents binding of EGF ligand and activation of the receptor. As a result, the tumor cells reduce secretion of vascular hypertrophy factors, decreasing blood vessel formation and increasing the number of dead cells through apoptosis (32). This is in accordance with our result indicating that treatment with $\mathrm{MeV}$ and nimotuzumab increased cytotoxicity and initialized apoptosis signaling. Moreover, nimotuzumab also plays a role in promoting other mechanisms of the immune response such as $\mathrm{T}$ and NK cells and contributes to cytotoxicity dependent effects (33).

Therapeutic regimens using the monoclonal antibodies have greatly changed the paradigm for treatment of cancer. Recently, the combination of nimotuzumab with other cancer therapies such as chemoradiotherapy has been used for the treatment of several cancers including esophageal cancer (15), LSCC (16), and advanced nasopharyngeal carcinoma (17). Another study have shown radiation-enhancing effects when using the combined treatment of nimotuzumab and celecoxib in human nasopharyngeal carcinoma cells, suggesting that this could be a promising approach for the treatment of poorly differentiated nasopharyngeal carcinoma (12). Accordingly, we showed here that the combination of $\mathrm{MeV}$ with nimotuzumab significantly increased cytotoxic activity in laryngeal cancer in vitro and in vivo, signifying a great potential of the combined use of oncolytic virus with monoclonal antibodies such as nimotuzumab in the treatment of various cancers.

In conclusion, these results showed a strong anticancer effect of $\mathrm{MeV}$ in combination with nimotuzumab in the treatment of laryngeal cancers in vitro and in vivo compared to a single therapy. Combination of oncolytic viruses and monoclonal antibodies should be considered for improving the efficiency of cancer treatment.

\section{Conflicts of Interest}

All Authors have no conflicts of interest to declare.

\section{Authors' Contributions}

NLT and HAS supervised the study and contributed to the materials and reagents. NLT, NTH, NY, HVT and HAS participated in the study design. NTH, NTX performed the experimental procedures. HVT, NLT and NTH analyzed data, interpreted results, and wrote 
the manuscript. NKL, CVM, NVB, NTX and TDC contributed to the materials and revision of the manuscript. All authors agreed with both the results and conclusions.

\section{Acknowledgements}

This study was funded by Vietnam National Foundation for Science and Technology Development (NAFOSTED) under grant number 106-YS.06-2013.22.

\section{References}

1 Callaway C: Rethinking the head and neck cancer population: The human papillomavirus association. Clin J Oncol Nurs 15(2): 165170, 2011. PMID: 21444283. DOI: 10.1188/11.CJON.165-170

2 Bray F, Ferlay J, Soerjomataram I, Siegel RL, Torre LA and Jemal A: Global cancer statistics 2018: Globocan estimates of incidence and mortality worldwide for 36 cancers in 185 countries. CA Cancer J Clin 68(6): 394-424, 2018. PMID: 30207593. DOI: $10.3322 /$ caac. 21492

3 Simard EP, Torre LA and Jemal A: International trends in head and neck cancer incidence rates: Differences by country, sex and anatomic site. Oral Oncol 50(5): 387-403, 2014. PMID: 24530208. DOI: 10.1016/j.oraloncology.2014.01.016

4 Miyamoto S, Inoue H, Nakamura T, Yamada M, Sakamoto C, Urata Y, Okazaki T, Marumoto T, Takahashi A, Takayama K, Nakanishi Y, Shimizu H and Tani K: Coxsackievirus b3 is an oncolytic virus with immunostimulatory properties that is active against lung adenocarcinoma. Cancer Res 72(10): 2609-2621, 2012. PMID: 22461509. DOI: 10.1158/0008-5472.CAN-11-3185

5 Msaouel P, Opyrchal M, Domingo Musibay E and Galanis E: Oncolytic measles virus strains as novel anticancer agents. Expert Opin Biol Ther 13(4): 483-502, 2013. PMID: 23289598. DOI: $10.1517 / 14712598.2013 .749851$

6 Son HA, Zhang L, Cuong BK, Van Tong H, Cuong LD, Hang NT, Nhung HTM, Yamamoto N and Toan NL: Combination of vaccine-strain measles and mumps viruses enhances oncolytic activity against human solid malignancies. Cancer Invest 36(2): 106-117, 2018. PMID: 29485292. DOI: 10.1080/07357907. 2018.1434539

7 Zhang LF, Tan DQ, Jeyasekharan AD, Hsieh WS, Ho AS, Ichiyama K, Ye M, Pang B, Ohba K, Liu X, de Mel S, Cuong BK, Chng WJ, Ryo A, Suzuki Y, Yeoh KG, Toan NL and Yamamoto N: Combination of vaccine-strain measles and mumps virus synergistically kills a wide range of human hematological cancer cells: Special focus on acute myeloid leukemia. Cancer Lett 354(2): 272-280, 2014. PMID: 25193462. DOI: $10.1016 /$ j.canlet.2014.08.034

8 Ong HT, Timm MM, Greipp PR, Witzig TE, Dispenzieri A, Russell SJ and Peng KW: Oncolytic measles virus targets high cd46 expression on multiple myeloma cells. Exp Hematol 34(6): 713720, 2006. PMID: 16728275. DOI: 10.1016/j.exphem.2006. 03.002

9 Buijs PR, Verhagen JH, van Eijck CH and van den Hoogen BG: Oncolytic viruses: From bench to bedside with a focus on safety. Hum Vaccin Immunother 11(7): 1573-1584, 2015. PMID: 25996182. DOI: $10.1080 / 21645515.2015 .1037058$

10 Peng KW, Ahmann GJ, Pham L, Greipp PR, Cattaneo R and Russell SJ: Systemic therapy of myeloma xenografts by an attenuated measles virus. Blood 98(7): 2002-2007, 2001. PMID: 11567982 .
11 Grote D, Russell SJ, Cornu TI, Cattaneo R, Vile R, Poland GA and Fielding AK: Live attenuated measles virus induces regression of human lymphoma xenografts in immunodeficient mice. Blood 97(12): 3746-3754, 2001. PMID: 11389012.

12 Huang J, Yuan X, Pang Q, Zhang H, Yu J, Yang B, Zhou L, Zhang $F$ and Liu F: Radiosensitivity enhancement by combined treatment of nimotuzumab and celecoxib on nasopharyngeal carcinoma cells. Drug Des Devel Ther 12: 2223-2231, 2018: PMID: 30038488. DOI: 10.2147/DDDT.S163595

13 Grandis JR and Tweardy TD: Elevated levels of transforming growth factor alpha and epidermal growth factor receptor messenger rna are early markers of carcinogenesis in head and neck cancer. Cancer Res 53: 3579-3584, 1993: PMID: 8339264.

14 Mateo C, Moreno E, Amour K, Lombardero J, Harris W and Perez $\mathrm{R}$ : Humanization of a mouse monoclonal antibody that blocks the epidermal growth factor receptor: Recovery of antagonistic activity. Immunotechnology 3(1): 71-81, 1997. PMID: 9154469.

15 Kato K, Ura T, Koizumi W, Iwasa S, Katada C, Azuma M, Ishikura S, Nakao Y, Onuma $\mathrm{H}$ and Muro K: nimotuzumab combined with concurrent chemoradiotherapy in japanese patients with esophageal cancer: A phase I study. Cancer Sci 109(3): 785793, 2018. PMID: 29285832. DOI: $10.1111 /$ cas.13481

16 Si X, Wu S, Wang H, Zhang X, Wang M, Zeng X and Zhang L: nimotuzumab combined with chemotherapy as first-line treatment for advanced lung squamous cell carcinoma. Thorac Cancer 9(8): 10561061, 2018. PMID: 29920955. DOI: 10.1111/ 1759-7714.12789

17 Lin M, You R, Liu YP, Zhang YN, Zhang HJ, Zou X, Yang Q, Li CF, Hua YJ, Yu T, Cao JY, Li JB, Mo HY, Guo L, Lin AH, Sun Y, Qian CN, Ma J, Mai HQ and Chen MY: Beneficial effects of anti-egfr agents, cetuximab or nimotuzumab, in combination with concurrent chemoradiotherapy in advanced nasopharyngeal carcinoma. Oral Oncol 80: 1-8, 2018. PMID: 29706183. DOI: 10.1016/j.oraloncology.2018.03.002

18 Mosmann T: Rapid colorimetric assay for cellular growth and survival: Application to proliferation and cytotoxicity assays. J Immunol Methods 65(1-2): 55-63, 1983. PMID: 6606682. PMID: 6606682.

19 O'Reilly S, Ciechomska M, Fullard N, Przyborski S and van Laar JM: Il-13 mediates collagen deposition via stat6 and microrna-135b: A role for epigenetics. Sci Rep 6: 25066, 2016. PMID: 27113293. DOI: 10.1038/srep25066

20 Hoan NX, Van Tong H, Giang DP, Toan NL, Meyer CG, Bock CT, Kremsner PG, Song LH and Velavan TP: Interferonstimulated gene 15 in hepatitis b-related liver diseases. Oncotarget 7(42): 67777-67787, 2016. PMID: 27626177. DOI: 10.18632/oncotarget.11955

21 Xiong H, Zhang ZG, Tian XQ, Sun DF, Liang QC, Zhang YJ, Lu R, Chen YX and Fang JY: Inhibition of jak1, 2/stat3 signaling induces apoptosis, cell cycle arrest, and reduces tumor cell invasion in colorectal cancer cells. Neoplasia 10(3): 287297, 2008. PMID: 18320073.

22 Mao H, Wang M, Cao B, Zhou H, Zhang Z and Mao X: Interferonstimulated gene 15 induces cancer cell death by suppressing the nf-kappab signaling pathway. Oncotarget 7(43): 70143-70151, 2016. PMID: 27659523. DOI: 10.18632/ oncotarget.12160

23 Domingo-Musibay E, Allen C, Kurokawa C, Hardcastle JJ, Aderca I, Msaouel P, Bansal A, Jiang H, DeGrado TR and Galanis E: Measles edmonston vaccine strain derivatives have potent oncolytic activity against osteosarcoma. Cancer Gene Ther 21(11): 483-490, 2014. PMID: 25394505. DOI: 10.1038/ cgt.2014.54 
24 Myers R, Harvey M, Kaufmann TJ, Greiner SM, Krempski JW, Raffel C, Shelton SE, Soeffker D, Zollman P, Federspiel MJ, Blanco $\mathrm{M}$ and Galanis E: Toxicology study of repeat intracerebral administration of a measles virus derivative producing carcinoembryonic antigen in rhesus macaques in support of a phase $\mathrm{i} / \mathrm{ii}$ clinical trial for patients with recurrent gliomas. Hum Gene Ther 19(7): 690-698, 2008. PMID: 18576918. DOI: 10.1089/hum 2008.035

25 Galanis E, Atherton PJ, Maurer MJ, Knutson KL, Dowdy SC, Cliby WA, Haluska P Jr., Long HJ, Oberg A, Aderca I, Block MS, Bakkum-Gamez J, Federspiel MJ, Russell SJ, Kalli KR, Keeney G, Peng KW and Hartmann LC: Oncolytic measles virus expressing the sodium iodide symporter to treat drug-resistant ovarian cancer. Cancer Res 75(1): 22-30, 2015. PMID: 25398436. DOI: 10.1158/0008-5472.CAN-14-2533

26 Vuorinen T, Peri P and Vainionpaa R: Measles virus induces apoptosis in uninfected bystander $\mathrm{t}$ cells and leads to granzyme $\mathrm{b}$ and caspase activation in peripheral blood mononuclear cell cultures. Eur J Clin Invest 33(5): 434-442, 2003. PMID: 12713458.

27 Liu C, Sarkaria JN, Petell CA, Paraskevakou G, Zollman PJ, Schroeder M, Carlson B, Decker PA, Wu W, James CD, Russell $\mathrm{SJ}$ and Galanis E: Combination of measles virus virotherapy and radiation therapy has synergistic activity in the treatment of glioblastoma multiforme. Clin Cancer Res 13(23): 7155-7165, 2007. PMID: 18056196. DOI: 10.1158/1078-0432.CCR-07-1306

28 Bhaskar A, Bala J, Varshney A and Yadava P: Expression of measles virus nucleoprotein induces apoptosis and modulates diverse functional proteins in cultured mammalian cells. PLoS One 6(4): e18765, 2011. PMID: 21533140. DOI: 10.1371/ journal.pone. 0018765
29 Everts B and van der Poel HG: Replication-selective oncolytic viruses in the treatment of cancer. Cancer Gene Ther 12(2): 141161, 2005. PMID: 15472714. DOI: 10.1038/sj.cgt.7700771

30 Segal BH, Wang XY, Dennis CG, Youn R, Repasky EA, Manjili $\mathrm{MH}$ and Subjeck JR: Heat shock proteins as vaccine adjuvants in infections and cancer. Drug Discov Today 11(11-12): 534-540, 2006. PMID: 16713905. DOI: 10.1016/j.drudis.2006.04.016

31 Zhang Y, Patel B, Dey A, Ghorani E, Rai L, Elham M, Castleton AZ and Fielding AK: Attenuated, oncolytic, but not wild-type measles virus infection has pleiotropic effects on human neutrophil function. J Immunol 188(3): 1002-1010, 2012. PMID: 22180616. DOI: $10.4049 /$ jimmunol.1102262

32 Qu YY, Hu SL, Xu XY, Wang RZ, Yu HY, Xu JY, Chen L and Dong GL: nimotuzumab enhances the radiosensitivity of cancer cells in vitro by inhibiting radiation-induced DNA damage repair. PLoS One 8(8): e70727, 2013. PMID: 23976954. DOI: 10.1371/journal.pone.0070727

33 Mazorra Z, Lavastida A, Concha-Benavente F, Valdes A, Srivastava RM, Garcia-Bates TM, Hechavarria E, Gonzalez Z, Gonzalez A, Lugiollo M, Cuevas I, Frometa C, Mestre BF, Barroso MC, Crombet $\mathrm{T}$ and Ferris RL: nimotuzumab induces nk cell activation, cytotoxicity, dendritic cell maturation and expansion of egfr-specific $\mathrm{t}$ cells in head and neck cancer patients. Front Pharmacol 8: 382, 2017. PMID: 28674498. DOI: 10.3389/fphar.2017.00382
Received March 27, 2019

Revised May 2, 2019

Accepted May 3, 2019 